\title{
Development of Online Learning Quality Assurance Management Model
}

\author{
Adelina Mariani S., ${ }^{1, *}$ \\ ${ }^{1}$ Lecturer at Bina Insani University, Indonesia \\ ${ }^{2}$ Doctoral Program in Educational Management, Universitas Negeri Semarang, Indonesia \\ *Corresponding author. Email: adelina.mariani80@gmail.com
}

\begin{abstract}
Bina Insani University is a university located in West Java that has been carrying out blended learning system courses for the last 3 years, including entrepreneurship courses. Online lectures are conducted after alternating faceto-face lectures. The existing learning materials with the blended learning system are already available. The Covid19 pandemic has caused lectures to be conducted online since February 2020. This is a problem because the online learning quality management model is not ready. Thus, it is demanded to develop an online learning quality assurance management model for entrepreneurship courses. This is qualitative research. Collecting data uses observation techniques and in-depth interviews. This study uses data reduction, data display, drawing conclusions and verification to analyze data. It is using a credibility test to assess their validity. In the process, researchers approached the Research and Develop (R\&D) process. In developing this model, online learning quality standards have been applied (evaluation of inputs, processes and outputs) and learning management by applying a knowledge management system (codification, collaboration, access). Management Model of Online Teaching Quality Assurance can effectively improve student learning. Qualitative and quantitative approaches will be very useful to see more deeply the effectiveness of the teaching materials being developed
\end{abstract}

Keywords: Online learning, Quality assurance, Knowledge management system, Covid-19.

\section{INTRODUCTION}

Corona Virus shocked all industries [1]. Schools and campuses were among the first to close in order to avoid mass gatherings [2]. This has led to a condition where all education must use the online learning platform. All educational institutions, whether they are prepared or not prepared, must strive to face the challenges of online learning.

There are many challenges of online learning ranging from the lack of technological knowledge to bad network coverage. Students face a lack of supervision; students may claim that they are studying but in fact, they are playing games or watching movies. For educators, it is essential to master the tools for online learning to make their classes engaging [2]. Campuses on the other hand must deal with quality assurance; the quality of online learning, if left unchecked, will cause students to suffer from a boring and uninteresting tutelage thus making the institution less credible [3-6].

Bina Insani University has been carrying out blended learning system courses for the last 3 years, including entrepreneurship courses. Online lectures are conducted after alternating face-to-face lectures. The existing learning materials with the blended learning system are already available. The Covid-19 pandemic has caused lectures to be conducted online since February 2020. The preliminary study shows This is a problem because the online learning quality management model is not ready. Thus, an online learning quality assurance management model for the entrepreneurship course is a must. The objectives of this study were:

1) To develop an online learning quality assurance management model for the entrepreneurship course.

2) Developing a physical model of online learning quality assurance management for the entrepreneurship course.

3) Measuring the effectiveness of the online learning quality assurance management model for the entrepreneurship course.

Formulations of the problem were as follow: 
1) What is the online learning quality assurance management model for the entrepreneurship courses?

2) How is the learning material model for the online learning quality assurance management model for the entrepreneurship course as a product of the development process above?

3) Is the online learning quality assurance management model for the entrepreneurship course effective?

\section{METHOD}

This is qualitative research. Collecting data uses observation techniques and in-depth interviews. This study used 4 steps of data analysis, namely data reduction, data display, drawing conclusions and verification. Furthermore, the results of the research data were carried out by a credibility test to assess their validity.

This study uses the Research and Develop (R\&D) approach. The $R \& D$ process starts from identifying learning objectives, analyzing the learning process, analyzing the student's characteristics, writing goals specifically for developing assessment instruments, making learning strategies, formulating the teaching materials and developing formative evaluations, design revisions, designing summative evaluations [7]

\section{RESULT AND DISCUSSION}

Quality Assurance Management Model Developed: Online Learning with Knowledge Management System Approach

Knowledge management system is a comprehensive software development built on three interconnected components, namely codification, collaboration, and access [8]. This codification focused on documenting, storing for easy retrieval, explicit knowledge. Perhaps the codified knowledge management system is best known as a public library. Almost anyone can quickly find the sources they are looking for in any library, including those they have never found before. The other side of knowledge management is collaboration. The birth of online communities and the networks that it uses has brought about a new category for collaborative tools called social software, that move significantly outside the classroom to embrace e-mail, discussion threads, chat rooms, instant messaging, synchronous conferencing tools, and other technologies. This new technology puts people in touch with each other, frequently and in real time. They also help identify who is available and when, use filters to aim at the correct skill set, and ultimately document these interactions for codification as explicit knowledge.

The interaction between codification and collaboration is how to encourage value in knowledge management. The key is to synchronize all knowledge into a clear common access strategy, where all knowledge seekers can quickly find what they are looking for, and all knowledge providers can contribute information and expertise in the same way and make it easy to find. It is not enough just with information on websites, online training, sharing documents, or in countless email boxes, because knowledge seekers still do not know where it is or how to find it. The new search technology enables knowledge seekers to match the source of knowledge (in metatags) and display it in the portal, where the portal becomes the entry point for the intellectual capitalists of an organization. This process makes knowledge discoverable to everyone.

Important features of a knowledge management system include explicit support for: 1. communication (eg, e-mail, bulletin boards, group messaging), 2 . coordination (eg, shared calendars, tasking groups, etc.); 3. collaboration (for example, artefacts can be shared, co-working space, etc.); and 4. controls (eg, version and configuration control, auditing, document locking, etc.). All abilities support work groups on complex tasks [9].

The key characteristics of a knowledge management system are [10]: (1) communication between users, (2) coordination of user activities, (3) collaboration between groups of users on the modification, creation and distribution of knowledge, and, (4) controlling the processes to ensure integrity and also to track progress. Systems that support knowledge management provide specialized functions related to communication (group chat and e-mail), coordination (linked calendars and task lists); collaboration (connected artefacts and workspace), and control (internal auditing and automatic control).

A knowledge management system contributes to a shared organizational culture by imparting a sense of belonging in the community and by asisting reciprocity between users [11]. The complexity of the 
problems and their solutions are very complex, knowledge management is needed so that it can be an effective reference for students, including through:

1) Grouping scientific developments and their applications in a database, grouping experts related to their expertise, grouping tools for solving scientific problems of sustainability in Indonesia, grouping learning resources;

2) Access and feedback arrangements;
3) Arrangement of student participant interaction (collaboration);

4) Communication arrangements;

5) Information retention and information recall.

Therefore, a knowledge management system (KMS) approach is needed in the development of web-based learning materials (online) through the implementation of its principles, namely codification, collaboration and access.

Table 1. Implications of Knowledge Management System in Strategy Development and Learning Materials

\begin{tabular}{|c|c|c|c|}
\hline No & $\begin{array}{c}\text { KMS } \\
\text { Principles }\end{array}$ & Development & Implications \\
\hline 1. & Codification & $\begin{array}{l}\text { 1. Knowledge Database (Learning } \\
\text { Materials) } \\
\text { 2. Learning Application Design } \\
\text { (Learning Materials) } \\
\text { 3. Training Program for the Use of } \\
\text { Learning Applications }\end{array}$ & $\begin{array}{l}\text { 1. Grouping knowledge based on } \\
\text { competencies and objectives. } \\
\text { 2. Grouping users } \\
\text { 3. Grouping other learning } \\
\text { resources }\end{array}$ \\
\hline 2. & Collaboration & $\begin{array}{l}\text { 1. Learning Community } \\
\text { 2. Group Discussion } \\
\text { 3. Communication and } \\
\text { Collaboration Applications } \\
\text { 4. Expert Resources } \\
\text { 5. Personal Documentation }\end{array}$ & $\begin{array}{l}\text { Creating forums among users to allow the } \\
\text { exchange of experiences, knowledge and } \\
\text { information as well as discussion of cases } \\
\text { involving community members and experts }\end{array}$ \\
\hline 3. & Access & $\begin{array}{l}\text { 1. Information Search } \\
\text { 2. Personalization } \\
\text { 3. User Interface } \\
\text { 4. Navigation } \\
\text { 5. Performance } \\
\text { Measurement }\end{array}$ & $\begin{array}{l}\text { Facilitate quick access via search or discovery } \\
\text { of knowledge according to the needs of } \\
\text { students. }\end{array}$ \\
\hline
\end{tabular}

\section{Effectiveness of Online Quality Assurance} Management Model with Knowledge Management System Principle Approach

The effectiveness of a learning program with regard to the problem of achieving learning objectives and the level of satisfaction of the individuals involved in learning. Learning is said to be effective if in the learning process each element functions as a whole, participants feel happy, satisfied with the learning results, make an impression, adequate facilities / facilities, affordable materials and methods, and professional teachers. The main review of the effectiveness of learning is its output, namely the competence of learners. Effectiveness refers to every element and components within the learning system functioning in line with the goals and objectives. Learning is effective if the preparation, implementation, and evaluation is in line to procedures and functions properly.

Thus in this study the Quality Assurance Management Model is implemented based on:

1) Learning Input: Evaluation of Learning Strategy Implementation, Utilization of Teaching Materials

Teaching materials can be categorized as teaching materials provided by the system (available directly on learning media) and

teaching materials that can be searched by students according to their needs through "browsing and searching". The results obtained from the use of this teaching material are that students still use the available materials more than they do by searching for materials themselves through browsing and searching facilities; 
2) Learning Process or Learning Activities: The learning process of students can be seen from the activities they carry out

Various facilities are provided as a medium for student collaboration to facilitate and increase the level of interaction, namely chatting, discussion forums, and email. The use of social media has been optimal and can effectively help with learning difficulties. Sharing and collaboration can be done in real time. The components of an online learning system that use the principles of the Knowledge Management System can be seen in Table 2;

3) Learning Outcomes

As explained above, the learning outcomes of students using the software include Learning Activity Track Records, Completion of Learning Exercises, Learning Feedback (Student Sources \& Expert Resources).

Table 2. The Effectiveness of Management Quality Assurance Model Using KMS

\begin{tabular}{lll} 
No & $\begin{array}{c}\text { Principles } \\
\text { of KMS }\end{array}$ & Development of KMS \\
\hline & 1. & $\begin{array}{l}\text { Knowledge Database } \\
\text { (Learning Materials) }\end{array}$ \\
& 2. $\begin{array}{l}\text { Learning Application } \\
\text { Design (Learning } \\
\text { Materials) }\end{array}$ \\
& 3. $\begin{array}{l}\text { Training Program for the } \\
\text { Use of Learning } \\
\text { Applications }\end{array}$ \\
1. Codification &
\end{tabular}

\section{Utilization of Online Learning System Components}

1. All students learn all teaching materials which are uploaded into the system according to the order, method and time specified.

2. What is lacking in this principle is the addition and management of knowledge databases.

3. Users rarely add new knowledge and only rely on the knowledge prepared by the admin (system managers and experts).

4. As the essence of a knowledge management system is knowledge sharing, how users create or present knowledge will be a determining factor for the success of this system.

1. Learning Community

2. Group Discussion

3. Communication and

2. Collaboration Collaboration Applications

4. Expert Resources

5. Personal Documentation
All of these components are in the online learning system. All of these components have been put to good use. Students find it helpful in learning by using this component and find it easier to understand and master the lesson. In conclusion, computers facilitate communication, collaboration, coordination, and control.

1. Information Search

2. Personalization

3. User Interface

3. Access

All of these components are already in the online learning system. All of these components have been put to good use. However, these applications still need to be improved in

5. Performance Measurement terms of access speed and interface design (if necessary analyzed by interface experts).

\section{CONCLUSION}

Management Model of Online Teaching Quality Assurance can effectively improve student learning. From the start of learning input, the implementation of learning strategies can be carried out in accordance with the blueprint developed, and the optimal use of teaching materials. Furthermore, from the learning process, various facilities are provided as a media for student collaboration to facilitate and increase the level of interaction, namely chatting, discussion forums, and

email. Knowledge management components function well and are optimally utilized in supporting learning.

Finally, from the learning results those students can understand well the learning that is being carried out and can do well all the stages of learning. When compared to face-to-face learning in class, online learning can be effective and has the potential to remove obstacles and provide a level of comfort, flexibility, more efficient material investment, learning can be adjusted anytime and anywhere and provide feedback. Besides that, the main difference between 
online learning and face-to-face class is the delivery and interaction system.

It is necessary to conduct a formative \& summative evaluation of the learning materials developed. Qualitative and quantitative approaches will be very useful to see more deeply the effectiveness of the teaching materials being developed. Furthermore, a quantitative approach can be done by conducting experiments.

\section{REFERENCES}

[1] Dennis MJ. Post-COVID-19 threats to higher education. Enroll Manag Rep. Wiley; 2020 Nov;24(8):3-3.

[2] Sinha B. Post-COVID Challenges and Opportunities in the Education Sector. SSRN Electron J [Internet]. Elsevier BV; 2020 Oct 15 [cited 2020 Dec 29]; Available from: https://papers.ssrn.com/sol3/papers.cfm?abstract id $=3710846$

[3] Froman B, Froman B, Pierce T. The Concepts of Quality Management and Quality Assurance. In: Guide to Preparing the Corporate Quality Manual [Internet]. CRC Press; 2020 [cited 2020 Dec 22]. p. 5-12. Available from: https://www.taylorfrancis.com/chapters/concepts -quality-management-quality-assurance-bernardfroman-tony-pierce/10.1201/9781003064664-3

[4] Direktorat Penjaminan Mutu. Pedoman Sistem Penjaminan Mutu Pendidikan Tinggi [Internet]. Kemenristek Dikti; 2016. 1-96 p. Available from:

http://sipma.ui.ac.id/files/dokumen/u_spmi_dikti/ pedoman-sistem-penjaminan-mutu-dikti-rev-2803-2016.compressed.pdf

[5] The University of Melbourne. Quality Assurance pf Online Learning Toolkit [Internet]. 1st ed. Melbourne: the Melbourne Centre for the Study of Higher Education at The University of Melbourne; 2017. 37 p. Available from: http://library1.nida.ac.th/termpaper6/sd/2554/197 55.pdf

[6] Rifa'i AA. Sistem Penjaminan Mutu Pendidikan Tinggi di Indonesia. Edugama J Kependidikan dan Sos Keagamaan [Internet]. 2019;5(1):15575. Available from: https://jurnal.lp2msasbabel.ac.id/index.php/edu/a rticle/view/963/393

[7] Bennett N, Borg WR, Gall MD. Educational Research: An Introduction [Internet]. 8th ed. Boston: Pearson/Allyn \& Bacon; 2007 [cited 2020 Dec 29]. 274 p. Available from: https://www.worldcat.org/title/educationalresearch-an-introduction/oclc/62741504

[8] Saade R, Nebebe F, Mak T. Knowledge Management Systems Development: Theory and Practice. Vol. 6, Interdisciplinary Journal of Information, Knowledge, and Management. 2011.

[9] Petrides LA, Nodine TR. Knowledge Management in Education: Defining the Landscape. 2003.

10] Hsia T-L, Lin L-M, Wu J-H, Tsai H-T. Interdisciplinary Journal of Information, Knowledge, and Management A Framework for Designing Nursing Knowledge Management Systems. 2006.

[11] Kamal PNM, Buniyamin N. Knowledge Management System in Industries. In: 2018 4th International Conference on Electrical, Electronics and System Engineering, ICEESE 2018 [Internet]. Institute of Electrical and Electronics Engineers Inc.; 2018 [cited 2020 Dec 29]. p. 107-11. Available from: https://www.researchgate.net/publication/332824 623_Knowledge_Management_System_in_Indus tries 